РОСІЙСЬКО-УКРАЇНСЬКИЙ КОНФЛІКТ: ПРОГНОЗИ ТА СЦЕНАРІЇ

\author{
Оксана Запорожець, Наталія Бєлоусова \\ Київський національний університет імені Тараса Шевченка, \\ вул. Мельникова, 36/1, м. Київ, Украӥна, 04119, тел.: +38044 481-45-09, \\ e-mail:oxana-za@yandex.ru; bnnb@ukr.net
}

\begin{abstract}
Проаналізовано прогнози українських експертів щодо подальшого розвитку подій на Сході України та визначено найвірогідніший сценарій російсько-українського конфлікту. 3'ясовано, що прогнози експертів $є$ ситуативними й короткотерміновими. Ситуацію на Донбасі оцінено як важкопрогнозовану, що не буде врегульована у найближчі роки. Можливими сценаріями розвитку російсько-українського конфлікту визначено «війну», «дестабілізацію» (стан між миром і війною, «тліючий конфлікт»), «заморожування» (припинення бойових дій без підписання мирного договору), «перемир'я» (призупинення бойових дій 3 розміщенням на території Донбасу миротворчого контингенту) та «перемогу» (відновлення українською армією контролю над територією Донбасу). Найвірогіднішим сценарієм розвитку російсько-українського конфлікту є «дестабілізація» (ймовірність - 75 \%). Такий сценарій вигідний, насамперед, для РФ та США, 3 точки зору реалізації їхніх геополітичних цілей.

Ключові слова: російсько-український конфлікт; українські експерти; прогнози; сценарії.
\end{abstract}

Російська інтервенція до Криму, проголошення «народних республік», війна на Сході України - резонансні події, що протягом року залишаються об'єктом пильної уваги політичних лідерів багатьох країн світу, міжнародних засобів масової інформації; їх активно обговорюють в експертному середовищі. Чисельні спроби визначення тенденцій, перспектив, сценаріїв подальшого розвитку ситуації в Україні відрізняються не тільки методом прогнозування та часовим інтервалом, а й рівнем достовірності та маніпулятивності.

Розглядаючи ситуацію, що склалася в Україні, як нелінійну систему 3 постійно зростаючими чинниками невизначеності, нестабільності та непередбачуваності не тільки зовнішніх, а й внутрішніх політичних, соціальних й економічних процесів, на наш погляд, найдоцільнішим $є$ використання сценарного методу як ефективного прогнозно-аналітичного інструментарію.

Як науковий метод прогнозування сценарний аналіз сформувався у 50 70-х роках XX століття, багато в чому завдяки дослідженням «мозкових центрів» військово-стратегічного планування США (корпорація РЕНД, Гудзонський інститут, Інститут майбутнього, Інститут Манхеттена, Інститут Аллегені). Подальшому розвитку сценарного методу сприяли дослідження таких західних вчених, як П. Вак, Д. Белл, М. Меркхофер, А. Вінер, Г. Кан, Т. Гордон, О. Хелмер, М. Портер, П. Шумейкер, та інших. За використання сценарного підходу виникає невизначеність, пов'язана з суб'єктивністю суджень експертів. Отож важливою характеристикою сценарного прогнозування $\epsilon$ узгодженість думок експертного середовища, що суттєво зменшує невизначеність і підвищує

(C) Запорожець Оксана, Бєлоусова Наталія, 2015 
Оксана Запорожець, Наталія Бєлоусова

важливість прогнозу.

Сьогодні в інформаційному просторі України постійно циркулюють різноманітні висловлювання експертів щодо можливих варіантів подальшого розвитку російсько-українського конфлікту. Прогнози варіюються від надзвичайно загрозливих, в яких наголошують на високій імовірності повномасштабної агресії з боку Росії у короткотерміновій перспективі, до більшменш помірних, в яких йдеться про локалізований затяжний конфлікт зі спорадичними зіткненнями між сепаратистами (бойовиками) та українськими військовими. Зважаючи на високі маніпулятивні властивості будь-якого прогнозу, виникає питання щодо цілей такого прогнозування: наукове дослідження конкретних перспектив розвитку досліджуваного явища чи досягнення заздалегідь визначеного ефекту. Активне поширення таких експертних прогнозів засобами масової інформації всередині країни суттєво впливає на суспільні настрої, спричиняючи виплеск негативних емоцій, паніку та створюючи зайві інформаційні приводи для Російської Федерації.

За цих умов виникає необхідність у комплексному аналізі та узагальненні поширюваних у медіапросторі країни експертних прогнозів та оцінки вірогідності пропонованих варіантів розвитку російсько-українського конфлікту.

Метою дослідження $\epsilon$ визначення узгодженості думок українського експертного середовища щодо подальшого розвитку подій на Сході України та виокремлення найвірогіднішого сценарію російського-українського конфлікту.

Основою дослідження слугують прогнози українських експертів щодо розвитку подій на Донбасі за період з квітня 2014 року до квітня 2015 року.

Загалом опрацьовано прогнози понад 20-ти експертів, які представляють такі аналітичні центри України, як Центр Разумкова, Центр досліджень армії, конверсії та роззброєння, Інститут євроатлантичного співробітництва, Інститут політичного аналізу та міжнародних досліджень, Центр прикладних політичних досліджень «Пента», Інститут стратегічних досліджень «Нова Україна», Інститут глобальних стратегій, Агенція моделювання ситуацій, Український інститут аналізу та менеджменту політики тощо.

Здебільшого українські експерти зазначають, що ситуація $\epsilon$ важкопрогнозованою, зокрема, через непередбачуваність дій російського президента В. Путіна.

Відповідно, експерти пропонують різні варіанти розвитку подій на Сході України, а саме:

- повномасштабне вторгнення російських військ (С. Згурець, Г. Перепелиця, В. Бадрак, Т. Березовець, В. Карасьов, В. Небоженко, М. Гончар, К. Матвієнко, М. Сунгуровський, експерти Центру Разумкова);

- обмежене територією Донбасу вторгнення російських військ (П. Рудяков);

- введення російських миротворців (М. Сунгуровський, Г. Перепелиця);

- заморожування конфлікту (Р. Бортник, В. Небоженко, П. Рудяков, В. Фесенко, В. Карасьов, А. Срмолаєв, О. Маркєєва, Л. Поляков, С. Денисенко, експерти Центру Разумкова); 
- встановлення Росією контролю над Донбасом і розширення впливу сепаратистів на інші регіони (В. Фесенко);

- постійна дестабілізація ситуації на Донбасі (В. Бала, С. Таран, В. Горбач, Т. Березовець, О. Сушко, Р. Старовойтенко, С. Жеребецький);

- стан між миром і війною (А. Золотарьов, В. Фесенко);

- довготривала «холодна війна» (О. Сушко);

- перемир'я з розміщенням на території Донбасу міжнародного контингенту миротворців (В. Фесенко, В. Карасьов);

- відторгнення і проголошення незалежності Донбасу (А. Срмолаєв, О. Маркєєва, Л. Поляков, С. Денисенко);

- військова перемога української армії і встановлення статус-кво (А. Єрмолаєв, О. Маркєєва, Л. Поляков, С. Денисенко);

- автономний статус Донецької та Луганської областей у складі України (А. Єрмолаєв, О. Маркєєва, Л. Поляков, С. Денисенко) тощо [1; с. 5-10, 12; 13; c. 17-19].

Незважаючи на широкий спектр перелічених варіантів розвитку подій у російсько-українському конфлікті, більшість експертів не виключає повномасштабного вторгнення російських військ на територію України. Причому ймовірність війни варіюється від найменших значень (наприклад, у прогнозах Володимира Фесенка) до дуже високих (наприклад, у прогнозах Віктора Небоженка) [8; 13].

Українські експерти сходяться також на тому, що не слід розраховувати на швидке врегулювання конфлікту. Однак в експертному середовищі немає узгодженості щодо термінів завершення російсько-українського конфлікту. На думку одних експертів, попереду довготривала «холодна війна», Україна буде у цій війні на передовій і (Олександр Сушко) i, на жаль, Україна не має можливості впливати на подальший перебіг подій (Павло Рудяков). Інші ж експерти навіть прогнозують часові рамки вирішення конфлікту - від весни 2015 року (Руслан Бортник), 1,5-2-х років (Валентин Бадрак, Тарас Березовець, Сергій Таран), 2-3-х років (Віктор Небоженко, Андрій Золотарьов) до 7-9-ти років (Сергій Толстой), коли Україна зможе відновити мир на Донбасі та контроль над східними територіями [2-4; $11 ; 14]$.

За результатами експертного опитування, проведеного Центром Разумкова у жовтні 2014 року, у найближчій перспективі (1-2 роки) доволі реальним сценарієм розвитку відносин України та Росії $є$ заморожування конфлікту 3 подальшим періодом конфронтації без застосування зброї (такої думки дотримуються $60 \%$ опитаних експертів). Водночас не виключають варіант подальшої ескалації конфлікту з переходом до повномасштабної війни, до якого схиляються $27 \%$ опитаних експертів [15].

Окрім того: опитані експерти переконані, що у найближчі 1-3 роки позитивних змін у політиці РФ щодо України не відбудеться; 55 \% експертів не вбачають передумов для позитивних зрушень навіть у більш віддаленій перспективі (3-5 років). На думку $48 \%$ експертів, позитивні зміни можливі лише у довготерміновій перспективі (5-10 років) [16]. 
Оксана Запорожець, Наталія Бєлоусова

ISSN 2078-4333. Вісник Львівського університету. Серія міжнародні відносини. 2015. Випуск 36. Частина 3

Систематизація та узагальнення прогнозів українського експертного середовища дає змогу кластеризувати можливі сценарії розвитку російськоукраїнського конфлікту:

- «ВІЙНА»;

- «ДЕСТАБІЛІЗАЦІЯ»;

- «ЗАМОРОЖУВАННЯ»;

- «ПЕРЕМИР'Я»;

- «ПЕРЕМОГА».

Сценарій «ВІЙНА» передбачає широкомасштабне вторгнення російських військ (в рамках Донецької та Луганської областей, або ж по периметру українського кордону) із застосуванням усього арсеналу тактичного озброєння.

Сценарій «ДЕСТАБІЛІЗАЦІЯ» означає збереження напруженої ситуації на Донбасі за рахунок провокацій, обстрілів позицій української армії, локальних наступів терористів без масштабного втручання російської армії. Такий варіант розвитку подій експерти характеризують як «гойдалку між війною і миром» та «тліючий конфлікт».

Сценарій «ЗАМОРОЖУВАННЯ» («консервація» конфлікту) передбачає припинення збройного протистояння між учасниками конфлікту без підписання мирного договору та визначення статусу спірної території. Загроза поновлення конфлікту залишається.

Сценарій «ПЕРЕМИР’Я» характеризується призупиненням військових дій на досягнутій на той момент лінії фронту і розміщенням на території Донбасу міжнародного контингенту миротворців.

Сценарій «ПЕРЕМОГА» - це встановлення українською армією повного контролю над українсько-російським кордоном та відновлення миру на Сході України.

На основі аналізу прогнозів українських експертів визначено ймовірність кожного $з$ перелічених сценаріїв:

«ВІЙНА» - ймовірність реалізації $8 \%$; як малоймовірний, цей сценарій згадують у 65 \% прогнозів експертів;

«ДЕСТАБІЛІЗАЦІЯ» - ймовірність реалізації $75 \%$;

«ЗАМОРОЖУВАННЯ» - ймовірність реалізації $30 \%$;

«ПЕРЕМИР'Я»- ймовірність реалізації $12 \%$;

«ПЕРЕМОГА»- ймовірність реалізації $2 \%$.

Отже, найвірогіднішим сценарієм розвитку російсько-українського конфлікту найближчим часом буде, ймовірно, постійна дестабілізація ситуації з боку РФ на Сході України шляхом провокування спорадичних зіткнень між бойовиками та українською армією.

Значна вірогідність такого сценарію зумовлена, на нашу думку, насамперед вигідністю для Росії. Передусім, підтримка напруженої ситуації на Донбасі створює перешкоди для нормального політичного та економічного розвитку України й фактично унеможливлює подальшу європейську та євроатлантичну інтеграцію держави, що відповідає геополітичним інтересам РФ. Цей сценарій також дає змогу Росії постійно здійснювати психологічний тиск на політичне 
керівництво України, домагаючись бажаних поступок й утримуючи Україну у статусі «підконтрольної/керованої території».

Окрім того, відсутність прямих військових атак за участі російської армії позбавить США та ЄС підстав для посилення або впровадження нових санкцій проти РФ, а також реалізації додаткових заходів для зміцнення власної обороноздатності. У перспективі можна припустити, що довготривале існування локалізованого нестабільно мирного стану спричинить певне звикання західних країн і зниження «відчуття російської загрози».

3 точки зору США, нестабільна ситуація на Сході України відкриває широкі можливості для маніпулювання громадською думкою та здійснення впливу на рішення та дії політичного керівництва багатьох країн світу. США зможуть протягом тривалого часу дотримуватись формату «холодної війни», використовуючи ситуацію для підвищення свого іміджу як єдиної країни, здатної реально стримувати нову «імперію зла», відстоювати демократичні цінності у світовому масштабі та захищати існуючий світовий порядок, заснований на усталених нормах і принципах міжнародного права.

Завдяки ефективному управлінню інформаційними потоками, створенню переконливої «картини світу», США і надалі посилюватимуть свій вплив на міжнародній арені, нівелюючи можливий опір та розширюючи коло своїх союзників. Як наслідок, створюватимуть сприятливі умови для послаблення Росії як актора міжнародних відносин i серйозного конкурента США у міжнародній політиці.

Для Європейського Союзу збереження нестабільної ситуації на Сході України матиме, імовірно, несприятливі наслідки, а саме:

- невирішеність конфлікту поблизу кордонів $€ С$ є джерелом постійної небезпеки;

- така ситуація заважатиме повноцінному співробітництву (насамперед економічному) з РФ, що завдає шкоди інтересам країн ЄС;

- збереження стану «між миром і війною» на Донбасі завдає удару по іміджу і репутації СС як сильного актора міжнародних відносин, оскільки може розцінюватись як провал посередницьких зусиль Німеччини та Франції у врегулюванні конфлікту та, як наслідок, нездатність цього об'єднання ефективно вирішувати проблеми на європейському просторі.

3 точки зору України, зазначений сценарій $є$ абсолютно невигідним, оскільки суперечить національним інтересам і цілям на міжнародній арені. Стратегічні зовнішньополітичні цілі України (вступ до НАТО і СС) стають недосяжними, якщо у країни $\epsilon$ невирішені територіальні проблеми. Стан «між миром і війною» буде виснажливим для держави як з економічної та військової, так і з моральнопсихологічної точок зору. Нездатність політичного керівництва швидко врегулювати конфлікт, зупинити кровопролиття буде постійним джерелом невдоволення 3 боку населення, яке вже відчуває погіршення соціальноекономічних умов життя, незахищеність і невпевненість у майбутньому. За цих умов зростає ймовірність поширення нестабільності загалом у країні, зокрема через антиурядові масові акції протесту. 
Отже, здебільшого прогнози експертів мають ситуативний характер i розраховані на короткотермінову перспективу (1-3 роки). В результаті виконаного дослідження 3'ясовано, що найвірогіднішим сценарієм розвитку подій є «дестабілізація» - ситуація, за якої Україна, на відміну від інших прямих і непрямих учасників конфлікту, залишається в програші. Водночас доволі згадуваним в експертному середовищі варіантом розвитку російськоукраїнського конфлікту $є$ малоймовірний сценарій «війна», що підтверджує маніпулятивні властивості прогнозів і схильність ЗМІ до сенсаційних заяв.

\section{СПИСОК ВИКОРИСТАНОЇ ЛІТЕРАТУРИ}

1. Березовеи T. Три базовых сценария в Донбассе [Электронный ресурс] / Т. Березовец. Режим доступа : http://nv.ua/opinion/berezovets/tri-bazovyh-scenariya-v-donbasse-19883.html.

2. Війна на Донбасі затягнеться на два-три роки [Електронний ресурс] / В. Небоженко. Режим доступу : http://wartime.org.ua/12376-vyna-na-donbas-zatyagnetsya-na-dva-tri-roki-nebozhenko. html.

3. Волконская И. П. Рудяков: Первый этап войны на Донбассе завершится к лету 2015 года [Электронный ресурс] / И. П. Волконская. - Режим доступа : http://provokacia.net/uncategory/ 14_11_25_pavel_rudyakov_pervyiy_etap_voynyi_na_donbasse_zavershitsya_k_letu_2015_god.

4. Донбасс будет тлеть еще 2-3 года - политолог [Электронный ресурс]. - Режим доступа : http://fakty.ictv.ua/ru/index/read-news/id/1548124.

5. Експерти пророкують Донбасу тліючий конфлікт [Електронний ресурс]. - Режим доступу : http://www.unian.ua/society/1037760-eksperti-prorokuyut-donbasu-tliyuchiy-konflikt.html.

6. Ермолаев A. Будущее территорий конфликта на Донбассе после Минских договоренностей-2: пространство вариантов [Электронный ресурс] / А. Ермолаев, О. Маркеева, Л. Поляков, С. Денисенко. - Режим доступа : http://newukraineinstitute.org/new/526.

7. Майная Н. Політолог Григорій Перепелиця: в Путіна $\epsilon$ три сценарії війни проти України [Електронний ресурс] / Н. Майная. - Режим доступу : http://glavred.info/politika/grigoriyperepelicya-mandat-na-vvedennya-mirotvorciv-rosiya-mozhe-otrimati-vid-snd-287001.html.

8. Майная Н. Вторжение России: как далеко может зайти Путин, и что делать Украине [Электронный ресурс] / Н. Майная. - Режим доступа : http://glavred.info/politika/kak-daleko-poydetputin-v-ukraine-ocenki-ekspertov-289081.html

9. Майная Н. Угроза вторжения: может ли Путин атаковать Восток и Юг Украины, прогноз экспертов [Электронный ресурс] / Н. Майная. - Режим доступа : http://glavred.info/politika/kakovaveroyatnost-vtorzheniya-rossii-ocenki-ekspertov-275994.html.

10. Матвійчук Я. Попереду Холодна війна без правил - Олександр Сушко [Електронний pecypc] / Я. Матвійчук. - Режим доступу : http://ukrainian.voanews.com/articleprintview/ 2460026.html.

11. Мащенко O. Валентин Бадрак: Переход к стабильному миру на востоке Украины может занять до двух лет [Электронный ресурс] / О. Мащенко. - Режим доступа : http://ukranews.com/ ru/interview/2014/06/09/507.

12. Мельник C. Конфлікт на Донбасі буде заморожений - експерт [Електронний ресурс] / С. Мельник. - Режим доступу : http://www.unn.com.ua/uk/news/ 1363131-konflikt-na-donbasi-budevirisheniy-shlyakhom-zamorozhuvannya-espert.

13. Нежина Л. Виктор Небоженко: Летом Россия попытается открыто вторгнуться в Украину [Электронный ресурс] / Л. Нежина. - Режим доступа : http://fraza.ua/interview/ 04.03.15/218468/viktor_nebozhenko_letom_rossija_popytaetsja_otkryto_vtorgnutsja_v_ukrainu.html

14. Политолог о войне на Донбассе: у Путина запаса прочности еще года на полтора [Электронный ресурс]. - Режим доступа : http://glavred.info/politika/politolog-o-voyne-na-donbasseu-putina-zapasa-prochnosti-esche-goda-na-poltora-310279.html.

15. Російсько-український конфлікт: стан, наслідки, перспективи розвитку подій // Національна безпека і оборона. - 2014. - № 5-6. - С. 27-30. 
16. Російсько-український конфлікт: позиції експертів // Національна безпека і оборона. 2014. - № 5-6. - С. 60-67.

17. Спрогнозувати дії Кремля на сході України майже неможливо [Електронний ресурс] / Микола Сунгуровський. - Режим доступу : http://www.razumkov.org.ua/ukr/expert.php? news_id=4935.

18. Тарасова B. Политолог предсказал возможный вариант событий на Донбассе [Електронний ресурс] / В. Тарасова. - Режим доступу : http://www.profi-forex.org/novostimira/novosti-sng/ukraine/entry1008239247.html.

19. Червоненко В. Чи почнеться масштабна війна на Донбасі? [Електронний ресурс] / В. Червоненко. - Режим доступу : http://www.bbc.co.uk/ukrainian/politics/2014/11/141105_future_ war_donbass_vc.

Стаття надійшла до редколегії 21.04.2015

Прийнята до друку 15.05.2015

\title{
RUSSIAN-UKRAINIAN CONFLICT: FORECASTS AND SCENARIOS
}

\author{
Oksana Zaporozhets, Natalia Belousova \\ Taras Shevchenko National University of Kyiv, \\ 36/1, Melnikova Str., Kyiv, Ukraine, 04119, tel.: +38044 481-45-09, \\ e-mail: oxana-za@yandex.ru; bnnb@ukr.net
}

The article focuses on the analysis of Ukrainian experts' forecasts concerning the events in the Donbas region and defines the most likely scenario of Russian-Ukrainian conflict. The study shows that the forecasts of Ukrainian experts are situational and short-range. According to the experts, the situation in the Donbas is unpredictable and will not be resolved in the nearest future. Therefore, a number of possible scenarios of Russian-Ukrainian conflict are examined: «war», «constant instability» (balancing between peace and war, smoldering conflict), «frozen conflict» (cessation of military actions without peace agreement), «truce» (ceasefire and deployment of peacekeeping mission in Donbas region), «victory» (regaining full control over Donbas region by Ukrainian troops). The most probable scenario for Russian-Ukrainian conflict is considered to be «constant instability» (estimated probability $75 \%$ ). The high probability of this scenario can be explained by its advantages primarily for Russia as well as for United States in achieving their geopolitical goals.

Key words: Russian-Ukrainian conflict; Ukrainian experts; forecasts; scenarios. 